20. LAUDER, E. (1914).-Ophthalmology, Vol. X, p. 251.

21. BIElschowsky (1916). - Münch. Med. Wochenschr., Vol. LXIII, p. 501.

22. DARIC (1916). - The Ophthalmoscope, p. 639.

23. Davies, D. Leighton (1916).-The Ophthalmoscope, Vol. XIV, p. 649.

24. BeCKeR (1920).-Ber. d. Deut. Ophthal. Ges., p. 294.

25. KoE PPE, L. (1921).-Klin. Monatsbl. f. Augenheilk., Vol. LXVI, p. 387.

26. SPIR, E. (1922).-Arch.f. Augenheilk., Vol. XC. p. 127.

27. . GJessing, H. G. A. (1922).-Brit. Jl. Ophthal., Vol. VI, p. 447.

28. Frese, H. (1922). -Arch. f. Augenheilk., Vol. XCI, p. 278.

29. Licskó, A. (1923).-Ref. Zentralbl. f. Ges. Ophthal., Vol. IX, p. 235.

30. BRUNER, W. E. (1924).-Amer. Jl. Ophthal., Vol. VII, p. 950. .

31. Horton, J. J. (1926).-Amer. Ji. Ophthal., Vol. IX, p. 84i.

32. Foussaret (1930). - La cataracte provoquée par l'electricité. Thése, Lyon.

33. Holloway, T. B. (1930).-Amer. Jl. of Ophthal., Vol. XIII, p. 595.

34. Cavka, V. (1930).-Zeitschr. f. Augenheilk., Vol. LXXI, p. 156.

35. WÜRDEMANN, H. V. (1932). - Injuries of the eye. H. Kimpton, London.

36. RHODES, D. H. (1932). -Amer. Jl. of Ophthal., Vol. XV, p. 1059.

37. HeCkel, E. B. (1932).-Amer. Jl. Ophthal., Vol. XV, p. 1059.

38. Weill, Nageldinger, Nordmann (1933).-Bull. Soc. Ophtal., Paris, pt. 1 , p. 292.

39. Gabrí́lides, A (1935).-Arch. d'Ophtal., Vol. LII, p. 394.

40. DJacos, C. (1936).-Arch. d'Ophtal., Vol. LIII, p. 454.

41. SKYDSGaARD, H. (1939).-Acta Ophthal., Vol. XVII, p. 470.

42. GodTFREDSE, E. (1942).-Acta Ophthal.

\title{
THE EFFECT OF ASCORBIC ACID ON THE OCCURRENCE OF HYPHAEMA AFTER CATARACT EXTRACTION*
}

BY

\author{
IDA MANN and A. PIRIE \\ NUFEIELD LABORATORY OF OPHTHALMOLOGY, \\ THE EYE HOSPITAL, OXFORD
}

CONTROVERSY over the causes and possible prevention of postoperative hyphaema after cataract extraction has continued from 1867 (the publication of the first series of 100 extractions performed by Von Graefe's method) until the present day. In 1942, de Voe, in a very complete clinical and experimental paper on the question, gave, as his list of possible causes to be investigated, the age of the patient, the season of the operation; the social status of the patient, the blood pressure, the presence of diabetes or syphilis; the intra-ocular pressure, the type of operation performed, including use or otherwise of sutures and of iridectomy, the skill of the surgeon, the use of retro-ocular injection, post-operative trauma, plasma vitamin $\mathrm{C}$ level, capillary fragility and prothrombin level of the blood. In a study of $\mathbf{4 5 3}$ cases of operation for cataract he found that variations in these factors were not related to the incidence of post-operative haemorrhage which throughout the series occurred in approximately 20 per cent. of the cases.

\footnotetext{
* Received for publication January 26, 1945.
} 
The basis of the opinion that ascorbic acid deficiency may increase post-operative haemorrhage lies in the work, summarised by Bourne (1942), which has shown that ascorbic acid is necessary for the healing of wounds; its absence prevents the synthesis of the intercellular supporting materials which form the framework for healing (Hojer (1924)). This has led ophthalmologists to try the prophylactic administration of ascorbic acid in cataract extraction on the warrantable assumption that the blood, which appears on the second to the tenth day after operation, comes from either the small newly formed blood vessels at the section or from the cut edges of the iris.

In studying the possible relation between plasma ascorbic acid level and hyphaema de Voe investigated 136 patients. He found that if the plasma level were over $0.5 \mathrm{mg}$. ascorbic acid per $100 \mathrm{ml}$. the occurrence of hyphaema was not influenced by the plasma ascorbic acid level. But of the five patients who had.a plasma ascorbic level below this value four had hyphaema. De Voe concludes that deficiency of ascorbic acid is not the common cause of hyphaema, but that if the intake of ascorbic acid is suspected of being low it is good practice to give ascorbic acid to the patient before operation.

Other workers have reported that dosage of an unselected group of patients with ascorbic acid reduced the incidence of hyphaema. Urbanek and Albrecht (1938) who saturated their patients with ascorbic acid by giving large doses on the day and subsequent to the day of operation, state that the tendency to post-operative bleeding is greatly reduced by such treatment: A similar result was claimed by Malling (1938).

Surveys of English wartime food have shown that, particularly in winter and early spring, it is deficient in ascorbic acid. It is therefore unlikely that the average plasma ascorbic acid level is as high hère and now as it was in the series of patients studied by de Voe in America. Richter and Croft (1943) found that the blood ascorbic acid of 350 normal factory workers from Birmingham varied from $0 \cdot 15-0.85 \mathrm{mg}$. per $100 \mathrm{ml}$. with an average of $-0.25 \mathrm{mg}$. These estimations were done in May, June and July, a time at which people are beginning to get early summer fruits and vegetables. Prunty and Vass (1944) found even lower levels of plasma ascorbic acid in a small series of hospital in-patients and Macbeth (1943) reported that the average plasma ascorbic acid for all hospital patients examined at the Radcliffe Infirmary, Oxford, in 1942 was $0.22 \mathrm{mg}$. per $100 \mathrm{ml}$. in January-April, $0.37 \mathrm{mg}$. in May-August and $0.2 \mathrm{mg}$. in September-December of that year.

If we are justified in assuming that ascorbic acid deficiency is a factor in the production of hyphaema it follows that we should be able to demonstrate this more clearly now than ever before, as 
the low ascorbic acid intake should lead to an increased incidence of hyphaema which should be reduced by saturation of the patient with ascorbic acid before operation. An experiment was therefore designed to settle this point.

Briefly, the results of all the cataract operations in our hospital for the year 1942-43, when ascorbic acid was not given, were compared with a similar series for 1943-44, with the difference that an attempt was made to saturate every patient in the latter series with ascorbic acid at the time of operation. All other factors such as surgeons, type of operation, diet in hospital, etc., remained the same throughout the two years.'

The records of all cataract operations done àt the Oxford Eye Hospital between August 1, 1942 and July 31, 1943, were collected and analysed and this group of 78 cases formed the base line for assessing the effect of ascorbic acid. From October 1, 1943, to June.30, 1944, all patients coming in for cataract extraction were given ascorbic acid tablets one month before they came in and told to take two $50 \mathrm{mg}$. tablets each day. If their admission was delayed a further supply was sent. In order to check whether the patients did in fact take the ascorbic acid a urine saturation test was done while in hospital awaiting operation. On the day following admission (patients are usually admitted two days before operation) $500 \mathrm{mg}$. ascorbic acid was given by mouth at 10 a.m. and a urine sample collected between $2-5$ p.m. into a bottle containing 20 c.c. glacial acetic acid. The ascorbic acid content of this sample was determined using the usual 2.6 dichlorphenol indo-phenol titration method. Different authors take different criteria in assessing saturation. Harris (1940) takes a $50 \mathrm{mg}$. excretion of ascorbic acid/10 stone body weight in a $2 \frac{1}{2}$ hours test period on the second day of dosing with $70 \mathrm{mg}$./stone body weight as evidence of saturation. On the other hand, Smith (1938) and Urbanek and Albrecht (1938) take 50 per cent. and Prunty and Vass (1943) a 33 per cent. excretion. of the test dose in 24 hours as saturation. We have used three hour urine samples taken four hours after the test dose when the rate of excretion is at its highest, so that we are not justified in multiplying the excretion during this period by eight to get the total 24 hour excretion. Instead we have taken a 5 per cent. excretion of the test dose, i.e., $25, \mathrm{mg}$. in the three hours test period as a satisfactory level of excretion. In addition to this test dose the day after admission, all the patients were given $100 \mathrm{mg}$. ascorbic acid a day while in hospital.

\section{Results}

The number of cataracts operated on in 1943-44 was much less than in the previous year owing to the fact that only battle casualties could be admitted after June 6 . In $1942-43$ there were 78 
extractions, but in 1943-44 there were only 39 as admission of waiting list cases was only possible during the nine.months under survey. The results are set out in Table I, which shows that the treatment with ascorbic acid has had no effect on the incidence of hyphaema.

TABLE I.-Incidence of hyphaema in 1942-43 and 1943-44

\begin{tabular}{c|c|c|c}
\hline Year & $\begin{array}{c}\text { Total number } \\
\text { of extractions }\end{array}$ & $\begin{array}{c}\text { Number of } \\
\text { hyphaema }\end{array}$ & $\begin{array}{c}\text { Percentage } \\
\text { hyphaema }\end{array}$ \\
\hline $1942-43$ & 78 & 20 & $25^{\circ} 6$ \\
$1943-44$ & 39 & 12 & $30 \% 7$ \\
\hline
\end{tabular}

Table II gives the results of the test of saturation with ascorbic acid, which tells us whether the patient did in fact take the tablets given to him during the month before operation. The average excretion of ascorbic acid during the test period of three hours by the uneventful cases was 10.3 per cent. of the test dose and the excretion by the hyphaema cases was 7.0 per cent. Four of the ten hyphaema cases had an excretion below 5 per cent. of the test dose, whereas only, two of the 25 uneventful cases had such low excretions. Two hyphaema cases were excluded from the estimation of saturation owing to changes in the time of urine collection.

TABLE II.-A scorbic acid excretion during 3 hour test period after a dose of $500 \mathrm{mg}$. ascorbic acid given 4 hours previously.

Percentage excretion of test dose

In uneventful cases

\begin{tabular}{rrrr} 
No. & & \multicolumn{1}{c}{ No. } \\
1 & $8^{\circ} 1$ & 14 & $9^{\circ} 8$ \\
2 & $11^{\circ} 1$ & 15 & $6^{\circ} 4$ \\
3 & $15^{\circ} \cdot$ & 16 & $9^{\circ} 0$ \\
4 & $11^{\circ} \cdot 2$ & 17 & $9^{\circ} 6$ \\
5 & $6^{\circ} 9$ & 18 & $9^{\circ} 6$ \\
6 & $4^{\circ} 8$ & 19 & $20^{\circ} 0$ \\
7 & $5^{\circ} 3$ & 20 & $15^{\circ} 2$ \\
8 & $12^{\circ} 0$ & 21 & $5^{\circ} 7$ \\
9 & $5^{\circ} \cdot 7$ & 22 & $10^{\circ} 9$ \\
10 & $0^{\circ} 0$ & 23 & $10^{\circ} 0$ \\
11 & $13^{\circ} 9$ & 24 & $14^{\circ} 0$ \\
12 & $8^{\circ} 0$ & 25 & $17^{\circ} 8$ \\
13 & $17^{\circ} 4$. & & \\
& & Average & $10^{\circ} 3$
\end{tabular}

In hyphaema cases

No.

- 14.5

29.0

$3 \quad 6^{\circ} 2$

$4 \quad 4^{\circ} 0$

$5 \quad 0^{\circ} 0$

$6 \quad 13 \cdot 8$

$7 \quad 10^{\circ} 0$

$8 \quad 10^{\circ} 0$

$9 \quad 10^{\circ} 6$

$10 \quad 24$

Average $7 \cdot 0$ 
EFFECT OF Ascorbic ACID ON THE OCCURRENCE OF HyphaEma after Cataract Extraction

Number of eases with excretion less than 5 per cent. of test dose during three hour period.

Uneventful cases $\frac{2}{25}$

Hyphaema cases $\frac{4}{10}$

At first sight this might seem to show, as de Voe thought, that, below a certain level, the less vitamin $C$ available the greater is the tendency to bleed. But the figures for. 1942-43 contradict this idea. In this year no ascorbic acid was given, so that the level of ascorbic acid saturation will have been even lower than that of the patients in 1943-44, who, even if they did not take the ascorbic acid at home, did get $500 \mathrm{mg}$. on test and then $100 \mathrm{mg}$. per day while in hospital. Yet the percentage of cases with hyphaema was less in 1942-43 than it was after ascorbic acid treatment. Ourresults, therefore, conflict with those of Urbanek and Albrecht and Malling and agree with those of de Vo'e in that we find that even in wartime England, where the population is generally low in ascorbic acid, saturation of the patient with ascorbic acid does not decrease the incidence of hyphaema after cataract extraction, all other conditions remaining the same.

\section{Summary}

There is no evidence that the occurrence of hyphaema following cataract extraction is influenced by administration of ascorbic acid.

We wish to thank Miss M. Barnett for technical assistance and Dr. A. Hirtenstein for the collection of the data for 1942-43 from the hospital records. It is a pleasure to record the assistance given by the surgeons and nursing staff of the Oxford Eye Hospital and the generous gift of ascorbic acid by Rochè Products Litd.

\section{REFERENCES}

BourNe; G.-Lancet, Vol. I I, p. 661, 1942.

HARRIS, L. J.-Lancet, Vol. II, p. 299, 1940.

Hojer, J. A.-Acta Paediat., Vol. III, p. 8, 1924.

MACBETH, R. G.-Jl. Laryn. and Otol., October, 1943.

MALLING, B.-Med. Rev., Vol. LV, p. 280, 1938.

PRUNTY, F. T. G. and VAss, C. C. N.-Lancet, Vol. I, p. 180, 1944.

PRUNTY, F. T. G. and VAss, C. C. N.-Biochem. Jl., Vol. XXXVII, p. 623, 1943.

Richter, D. and CRofT, P. G.-Biochem. Jl., Vol. XXXVII, p. 707, 1943.

Sмith, S. L.-Jl. Amer. Med. Assoc., Vol. CXI, p. 1753, 1938.

Urbanek, J. and Albrecht, W.-Zeitschr. f. Augenheilk., Vol. XCV; p. 129 1938.

DE VOE, G.-Arch. Ophthal., Vol. XXVIII, p. 1069, 1942. 